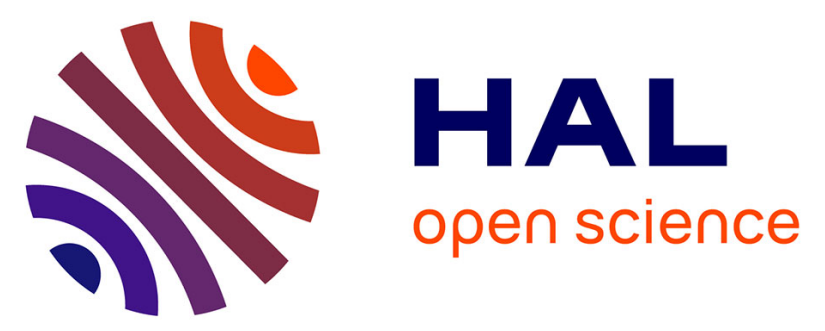

\title{
Ionothermal synthesis of polyanionic electrode material Na3V2(PO4)2FO2 through a topotactic reaction
}

Jacob Olchowka, Long H. B. Nguyen, Emmanuel Petit, Paula Sanz Camacho, Christian Masquelier, Dany Carlier, Laurence Croguennec

\section{- To cite this version:}

Jacob Olchowka, Long H. B. Nguyen, Emmanuel Petit, Paula Sanz Camacho, Christian Masquelier, et al.. Ionothermal synthesis of polyanionic electrode material Na3V2(PO4)2FO2 through a topotactic reaction. Inorganic Chemistry, 2020, 59 (23), pp.17282-17290. 10.1021/acs.inorgchem.0c02546 . hal03028092

\section{HAL Id: hal-03028092 \\ https://hal.science/hal-03028092}

Submitted on 7 Dec 2020

HAL is a multi-disciplinary open access archive for the deposit and dissemination of scientific research documents, whether they are published or not. The documents may come from teaching and research institutions in France or abroad, or from public or private research centers.
L'archive ouverte pluridisciplinaire HAL, est destinée au dépôt et à la diffusion de documents scientifiques de niveau recherche, publiés ou non, émanant des établissements d'enseignement et de recherche français ou étrangers, des laboratoires publics ou privés. 


\title{
Ionothermal Synthesis of Polyanionic Electrode Material $\mathrm{Na}_{3} \mathrm{~V}_{2}\left(\mathrm{PO}_{4}\right)_{2} \mathrm{FO}_{2}$ Through Topotactic Reaction
}

\author{
Jacob Olchowka ${ }^{\text {a,c,d,*, }}$ Long H.B. Nguyen ${ }^{\text {a,b,c }}$, Emmanuel Petit, ${ }^{\text {a,c, }}$ Paula Sanz \\ Camacho ${ }^{\mathrm{a}}$, Christian Masquelier, ${ }^{\mathrm{b}, \mathrm{c}, \mathrm{d}}$ Dany Carlier ${ }^{\mathrm{a}, \mathrm{c}, \mathrm{d}}$, Laurence Croguennec ${ }^{\mathrm{a}, \mathrm{c}, \mathrm{d}}$
}

${ }^{a}$ CNRS, Univ. Bordeaux, Bordeaux INP, ICMCB UMR 5026, F-33600, Pessac, France.

${ }^{\mathrm{b}}$ Laboratoire de Réactivité et de Chimie des Solides, CNRS-UMR\# 7314, Université de Picardie Jules Verne, F-80039 Amiens Cedex 1, France.

c RS2E, Réseau Français sur le Stockage Electrochimique de 1'Energie, FR CNRS 3459, F-80039 Amiens Cedex 1, France.

${ }^{\mathrm{d}}$ ALISTORE-ERI European Research Institute, FR CNRS 3104, Amiens, F-80039 Cedex 1, France.

\begin{abstract}
The polyanionic $\mathrm{Na}_{3} \mathrm{~V}_{2}\left(\mathrm{PO}_{4}\right)_{2} \mathrm{FO}_{2}$ has been successfully prepared for the first time by ionothermal reaction in the 1-Ethyl-3-methylimidazolium bis(trifluoromethylsulfonyl)imide (EMIM TFSI) ionic liquid. Its structure and elemental stoichiometry are confirmed by X-ray diffraction, NMR spectroscopy, and ICP-OES, respectively. Furthermore, the scanning electron microscopy reveals that the as-obtained material possesses an original platelet-like morphology. A topochemical reaction mechanism is proposed to explain the formation of the $3 \mathrm{D}$ framework of $\mathrm{Na}_{3} \mathrm{~V}_{2}\left(\mathrm{PO}_{4}\right)_{2} \mathrm{FO}_{2}$ from the layered compound $\alpha-\mathrm{VOPO}_{4} \cdot 2 \mathrm{H}_{2} \mathrm{O}$. Galvanostatic electrochemical tests indicate a modification of the desodiation and sodiation mechanism of the as-prepared $\mathrm{Na}_{3} \mathrm{~V}_{2}\left(\mathrm{PO}_{4}\right)_{2} \mathrm{FO}_{2}$ compared to those synthesized by conventional solid-state approaches. Furthermore, the electrochemical performance of $\mathrm{Na}_{3} \mathrm{~V}_{2}\left(\mathrm{PO}_{4}\right)_{2} \mathrm{FO}_{2}$ obtained at different cycling rates is also discussed.
\end{abstract}

KEYWORDS: Na-ion batteries, polyanionic positive electrode materials, ionothermal synthesis, $\mathrm{Na}_{3} \mathrm{~V}_{2}\left(\mathrm{PO}_{4}\right)_{2} \mathrm{FO}_{2}$, electrochemistry, topotactic reaction

* Corresponding author : J. Olchowka (Jacob.Olchowka@icmcb.cnrs.fr) 


\section{Introduction}

Sodium-ion batteries (SIBs) are nowadays considered as an efficient, reliable, and ecofriendly alternative to Lithium-ion batteries (LIBs) for large-scale electrochemical energy storage. ${ }^{1,2}$ Among the different polyanionic, layered oxides and Prussian blue analogs investigated as positive electrode materials for SIBs, the series of polyanionic materials $\mathrm{Na}_{3} \mathrm{~V}^{3+}{ }_{2-y} \mathrm{~V}^{4+}{ }_{y}\left(\mathrm{PO}_{4}\right)_{2} \mathrm{~F}_{3-y} \mathrm{O}_{y}(0 \leq y \leq 2)$ is one of the most promising. ${ }^{3-8}$ They are characterized by a stable 3D framework built of $\mathrm{V}_{2} \mathrm{O}_{8} \mathrm{~F}_{3-y} \mathrm{O}_{y}$ bioctahedral units and $\mathrm{PO}_{4}$ tetrahedra, high $\mathrm{Na}^{+}$-extraction voltages, and high theoretical capacities associated with the reversible extraction and re-insertion of two $\mathrm{Na}^{+}$ions per formula unit. Starting from the parental composition, $\mathrm{Na}_{3} \mathrm{~V}_{2}\left(\mathrm{PO}_{4}\right)_{2} \mathrm{~F}_{3}$, the substitution of oxygen for fluorine leads to the oxidation of $\mathrm{V}^{3+}$ into $\mathrm{V}^{4+}$ and to the formation of highly covalent vanadyl-type bonds, $\{\mathrm{V}=\mathrm{O}\}^{2+}$, which induces a progressive decrease in their operating voltage. ${ }^{9}$ Furthermore, oxygen substitution also enhances the $\mathrm{Na}^{+}$diffusivity within the diffusion channels and stabilizes the structure, especially at the overcharged states, ${ }^{9-11}$ making these oxygen-substituted compositions interesting for practical applications. ${ }^{4,8}$ In recent years, several synthetic approaches such as sol-gel, ${ }^{12,13}$ solvothermal, ${ }^{14-18}$ ball-milling, ${ }^{19,20}$ spark plasma sintering, ${ }^{21}$ and spray drying ${ }^{22}$ have been developed to optimize the carbon-coating layer, the morphology, and the particle size of $\mathrm{Na}_{3} \mathrm{~V}^{3+}{ }_{2-y} \mathrm{~V}^{4+}{ }_{y}\left(\mathrm{PO}_{4}\right)_{2} \mathrm{~F}_{3-y} \mathrm{O}_{y}$. The as-obtained materials crystallize in the form of hollow microspheres, nano or microcubes, spherical nanoparticles, 3D array, or nano-flower morphologies, which often exhibit outstanding performance at high cycling rates due to an enhanced electrode-electrolyte interface allowing a better ionic diffusion process. ${ }^{14,17,23,24}$ These achievements highlight the importance of structural engineering and a need to develop new synthesis approaches.

Ionic liquids (IL) are ideal solvents, widely used to synthesize shape-controlled inorganic or hybrid organic-inorganic materials. ${ }^{25-28}$ In a chemical reaction, they can serve as a template, a structure-directing agent, or even a reactant. For instance, tetrafluoroborate $\left(\mathrm{BF}_{4}{ }^{-}\right)$or hexafluorophosphate $\left(\mathrm{PF}_{6}{ }^{-}\right)$-based ionic liquids can be employed as a solvent but also as a fluoride source for the synthesis of fluoride-containing materials, which can thus avoid the use of the harmful hydrofluoric acid (HF) ${ }^{29-31}$ Furthermore, the use of ionic liquids has led to the development of the ionothermal synthesis approach, which then holds an essential role in the preparation of new electrode materials for $\mathrm{Li}$ and $\mathrm{Na}$-ion batteries, as highlighted in the pioneering work of Recham et al. ${ }^{32,33}$ For example, the Tavorite and Triplite fluoro-sulfates 
$\mathrm{LiMSO}_{4} \mathrm{~F}(\mathrm{M}=\mathrm{Fe}, \mathrm{Mn}, \mathrm{Co}, \mathrm{Ni})$ were identified as promising high-voltage materials for LIBs. However, being sensitive to air moisture and because sulfate precursors decompose at high temperature, conventional synthesis methods are not well adapted contrary to ionothermal synthesis approach for which IL medium prevents from air exposure. ${ }^{34,35}$ Moreover, the nature of the anionic part and the length of the alkyl chain on the cationic counterpart of the ionic liquid used in the ionothermal synthesis can significantly influence the morphology of the as-obtained products. ${ }^{32}$ A surface functionalization involving the grafting of ionic liquid molecules on the materials'surface can also occur during the synthesis step, which can later protect the electrode materials from moisture oxidation, and enhance their electrochemical performance upon cycling by improving their ionic transport properties. ${ }^{36-39}$

In this work, we will investigate the possible use of the ionothermal approach to synthesize the polyanionic compound $\mathrm{Na}_{3} \mathrm{~V}_{2}\left(\mathrm{PO}_{4}\right)_{2} \mathrm{FO}_{2}\left(\mathrm{NVPFO}_{2}\right)$ with an original morphology. The influence of this peculiar morphology on the electrochemical performance of the as-obtained material will also be studied in detail.

\section{Experimental Section}

\subsection{Materials preparation}

The $\alpha-\mathrm{VOPO}_{4} \cdot 2 \mathrm{H}_{2} \mathrm{O}$ precursor was obtained by refluxing a mixture of $\mathrm{V}_{2} \mathrm{O}_{5}$ (Sigma Aldrich, 99.6\%) and $\mathrm{H}_{3} \mathrm{PO}_{4}$ (Alfa Aesar, 80\%), four times in molar excess, in water for 24h. A yellowgreen product was obtained, cooled down to room temperature, filtered under vacuum, and washed several times with acetone. The recorded X-ray diffraction (XRD) pattern confirms a successful synthesis of $\alpha-\mathrm{VOPO}_{4} \cdot 2 \mathrm{H}_{2} \mathrm{O}$ (Figure S1). For the ionothermal synthesis of $\mathrm{Na}_{3} \mathrm{~V}_{2}\left(\mathrm{PO}_{4}\right)_{2} \mathrm{FO}_{2}$, a mixture containing $\mathrm{NaF}$ and $\alpha-\mathrm{VOPO}_{4} \cdot 2 \mathrm{H}_{2} \mathrm{O}$ in a $3 / 2$ molar ratio was first introduced in a $45 \mathrm{~mL}$ Teflon Parr autoclave, followed by $5 \mathrm{~mL}$ of 1-ethyl-3methylimidazolium bis(trifluoromethylsulfonyl)imide (EMI-TFSI). The mixture was stirred for $1 \mathrm{~h}$ at room temperature and then placed in a furnace at $220{ }^{\circ} \mathrm{C}$ for $16 \mathrm{~h}$. A greenish polycrystalline powder was recovered by centrifugation, washed several times with water and ethanol, and dried overnight at $80{ }^{\circ} \mathrm{C}$. Additionally, a reference sample of $\mathrm{Na}_{3} \mathrm{~V}_{2}\left(\mathrm{PO}_{4}\right)_{2} \mathrm{FO}_{2}$ was obtained by a solid-state reaction, as described earlier in Ref ${ }^{9}$. 


\subsection{Characterization techniques}

X-ray diffraction (XRD) measurements were carried out using a PANalytical Empyrean diffractometer in $\theta-\theta$ configuration, equipped with a $\mathrm{Cu} \mathrm{K}_{\alpha 1,2} \mathrm{X}$-ray source. The acquisition was performed in the $2 \theta$ angular range of $10^{\circ}-80^{\circ}$ with a step size of $0.0167^{\circ}$. The profile matching was performed using the FullProf Suite.

Scanning electron microscopy (SEM) images were taken on the metalized samples (Pddeposited) by a Hitachi Model S-4500 microscope.

The chemical analysis of the $\mathrm{Na}, \mathrm{P}$, and $\mathrm{V}$ contents was performed by inductively coupled plasma-optical emission spectroscopy (ICP-OES) using a Varian Model 720-ES spectrometer, after a dissolution of the powders into a concentrated hydrochloric acid $(\mathrm{HCl})$ solution.

Fourier transformed infrared (FT-IR) spectra were recorded using a Bruker Equinox 55 spectrometer in the wavenumber range of $400-4000 \mathrm{~cm}^{-1}$ (mid-IR) with a resolution of $4 \mathrm{~cm}^{-}$

${ }^{1}$. The samples were finely ground in a mortar with dried $\mathrm{KBr}$ in an approximate ratio of 3/50 (by wt.\%).

${ }^{31} \mathrm{P}$ solid-state-Nuclear Magnetic Resonance (ss-NMR) spectra were acquired on a Bruker Avance III 100WB (2.35 T) spectrometer (operating at Larmor frequency of $40.6 \mathrm{MHz}$ for ${ }^{31} \mathrm{P}$ ) equipped with a standard Bruker $2.5 \mathrm{~mm}$ magic-angle spinning (MAS) probe. A Hahn echo $(\pi / 2-\pi)$ sequence synchronized to one rotor period (MAS rate: $30 \mathrm{kHz}$ ) was used with a $\pi / 2$ pulse length of $1.1 \mu$ s and a recycle delay of $0.2 \mathrm{~s}$. Chemical shifts are referenced relative to an aqueous $85 \%$ solution of $\mathrm{H}_{3} \mathrm{PO}_{4}\left(\delta\left({ }^{31} \mathrm{P}\right)=0 \mathrm{ppm}\right)$.

${ }^{23} \mathrm{Na}$ ss-NMR spectra were acquired using a Bruker Avance III 500WB (11.7 T) spectrometer (operating at Larmor frequency of $132,3 \mathrm{MHz}$ for ${ }^{23} \mathrm{Na}$ ) equipped with a conventional $2.5 \mathrm{~mm}$ MAS probe. Single-pulse experiments were performed at $30 \mathrm{kHz}$ spinning rate with a short pulse length of $1 \mu$ s corresponding to a selective $\pi / 8$ pulse. The spectral width was set to 1 $\mathrm{MHz}$ and the recycle delay to $\mathrm{D}_{0}=0.2 \mathrm{~s}$, which was long enough to avoid $\mathrm{T}_{1}$ saturation effects. Chemical shifts are referenced relative to an aqueous $0.1 \mathrm{M}$ solution of $\mathrm{NaCl}$ solution $\left(\delta\left({ }^{23} \mathrm{Na}\right)=0 \mathrm{ppm}\right)$. 
The electrochemical properties of the materials were tested in CR2032-type coin cells. The positive electrodes were prepared as a mixture containing the active material, carbon black, and polytetrafluoroethylene (PTFE) in the 80/10/10 ratio (by wt.\%). The as-obtained mixture was pressed under 5 tons to form films with a thickness of $\sim 200 \mu \mathrm{m}$ and then dried overnight at $80^{\circ} \mathrm{C}$ under vacuum. A homemade electrolyte containing a $1 \mathrm{M}$ solution of $\mathrm{NaPF}_{6}(\mathrm{Strem}$ Chemical; 99\%) in ethylene carbonate and dimethyl carbonate $(\mathrm{EC} / \mathrm{DMC}=1 / 1)$ with $2 \mathrm{wt} . \%$ of fluoroethylene carbonate (FEC) was used for all the electrochemical tests. The assembled cells were cycled in galvanostatic mode, at a C/20 cycling rate between 2.8 and $4.5 \mathrm{~V}$ vs. $\mathrm{Na}^{+} / \mathrm{Na}$. The theoretical capacity being $130 \mathrm{mAh} \cdot \mathrm{g}^{-1}\left(2 \mathrm{Na}^{+}\right.$reversibly extracted), the rate $\mathrm{C} / 20$ corresponds to the exchange of $2 \mathrm{Na}^{+}$in 20 hours. The electrodes have a typical active mass loading around $10 \mathrm{mg} . \mathrm{cm}^{-2}$.

\section{Results and discussions}

\subsection{Structural, morphological and spectroscopic characterization}

The recorded XRD pattern shows that the material obtained from the ionothermal reaction has a structure similar to those of $\mathrm{Na}_{3} \mathrm{~V}^{3+}{ }_{2-y} \mathrm{~V}^{4+}{ }_{y}\left(\mathrm{PO}_{4}\right)_{2} \mathrm{~F}_{3-y} \mathrm{O}_{y}$ (Figure 1). In this material family, the $c$ parameter of the phases decreases linearly from 10.74666(6) to 10.6056(1) $\AA$ when moving from $\mathrm{Na}_{3} \mathrm{~V}_{2}\left(\mathrm{PO}_{4}\right)_{2} \mathrm{~F}_{3}$ to $\mathrm{Na}_{3} \mathrm{~V}_{2}\left(\mathrm{PO}_{4}\right)_{2} \mathrm{FO}_{2}{ }^{9}$. This evolution is characterized by a progressive substitution of the long V-F bonds $\left(d_{\mathrm{V}-\mathrm{F}}=1.981(2) \AA\right)$ by short vanadyl bonds $\left(d_{\mathrm{V}=\mathrm{O}}=1.620(1) \AA\right)$ along the $c$-direction. The diffraction peaks observed for the material obtained in ionothermal conditions can be indexed using an "average" unit cell described in the $P 4_{2} / m n m$ space group with $a=b=8.993(1) \AA$ and $c=10.623(1) \AA$, in good agreement with the cell parmaters of $\mathrm{Na}_{3} \mathrm{~V}_{2}\left(\mathrm{PO}_{4}\right)_{2} \mathrm{FO}_{2}$ obtained using laboratory X-ray diffractometer ( $\mathrm{c}$ $=10.622(5)) .{ }^{9}$ The actual structure of $\mathrm{Na}_{3} \mathrm{~V}_{2}\left(\mathrm{PO}_{4}\right)_{2} \mathrm{FO}_{2}$ is described in the $P 2_{1} / m$ space group with a modulation vector to take into account the long-range $\mathrm{Na}^{+}$ordering; nonetheless, the corresponding superstructure lines can only be observed with synchrotron XRD. Due to the limit of the instrumental resolution of the laboratory X-ray diffractometers used in this study, the "average" $\mathrm{Na}_{3} \mathrm{~V}_{2}\left(\mathrm{PO}_{4}\right)_{2} \mathrm{FO}_{2}$ structure was described in the $P 4_{2} / m n m$ space group. Besides $\mathrm{Na}_{3} \mathrm{~V}_{2}\left(\mathrm{PO}_{4}\right)_{2} \mathrm{FO}_{2}$, a small amount of $\mathrm{Na}_{0.5} \mathrm{VOPO}_{4} \cdot 2 \mathrm{H}_{2} \mathrm{O}$ impurity was also detected (Figures 1

and S2). ${ }^{40,41}$ Comparing to the $\mathrm{XRD}$ pattern of $\mathrm{NVPFO}_{2}$ obtained from the solid-state approach $\left(\mathrm{NVPFO}_{2}\right.$-ss, figure S2), the $\mathrm{NVPFO}_{2}$ powder synthesized from the ionothermal route shows a preferential orientation of the (002) plane, as indicated by the very intense 
diffraction line at $\sim 16.8^{\circ}$ (Figure S2). Furthermore, the elemental chemical analysis determined by ICP-OES reveals a Na/V/P ratio of $2.75 / 2 / 2$, and would thus indicate the presence of $\mathrm{Na}_{0.5} \mathrm{VOPO}_{4} \cdot 2 \mathrm{H}_{2} \mathrm{O}$ by $\sim 12 \mathrm{~mol} . \%$. Attempts to obtain a pure material by varying the reaction time remained unsuccessful.

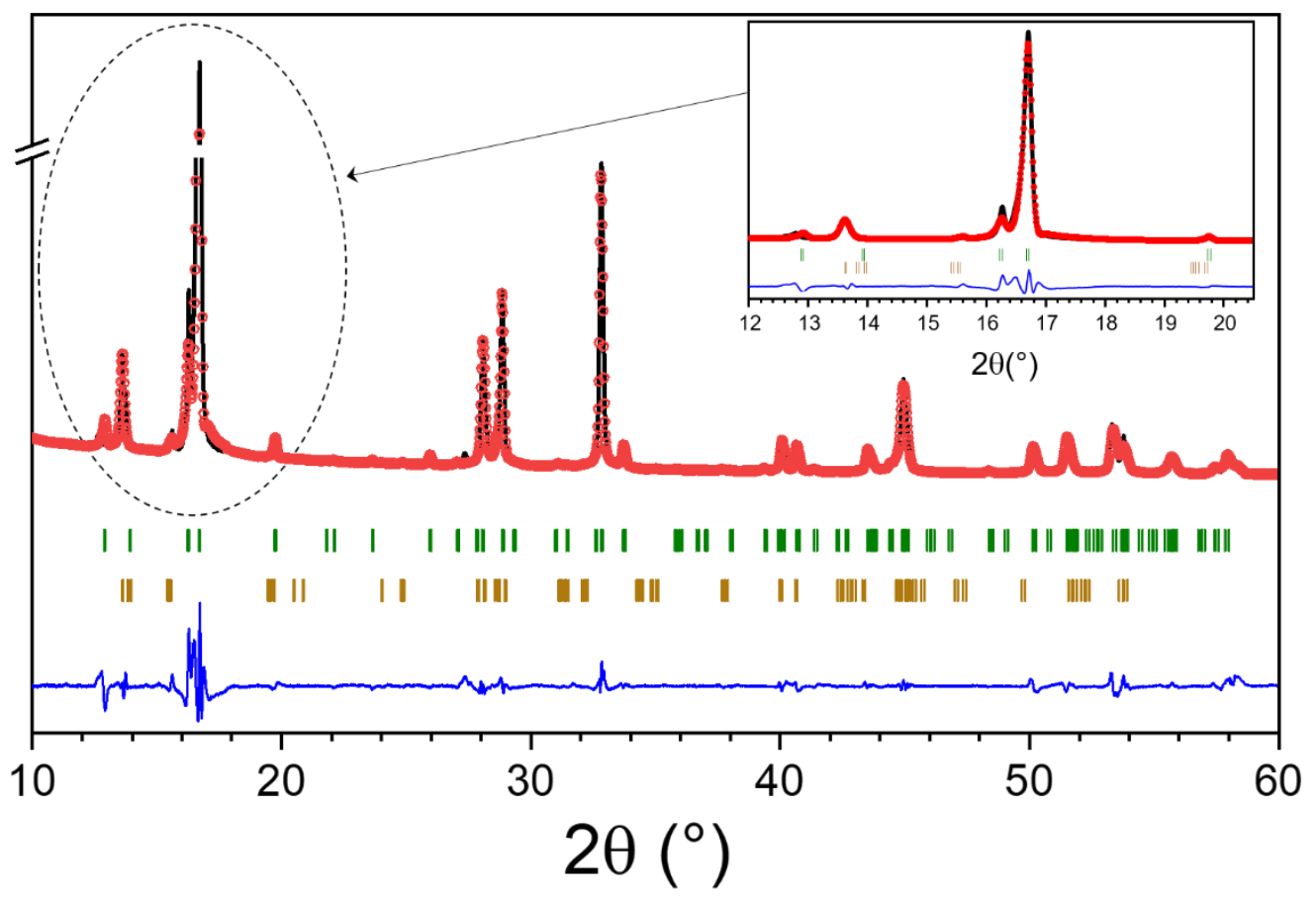

Figure 1: Profile matching of the XRD data recorded for $\mathrm{NVPFO}_{2}$ synthesized from ionothermal approach. The green and beige ticks indicate the diffraction peaks of $\mathrm{Na}_{3} \mathrm{~V}_{2}\left(\mathrm{PO}_{4}\right)_{2} \mathrm{FO}_{2}$ and $\mathrm{Na}_{0.5} \mathrm{VOPO}_{4} \cdot 2 \mathrm{H}_{2} \mathrm{O}$, respectively. The inset highlights the high intensity of the (002) diffraction peak and thus indicates the preferential orientation of the particles within the (ab) crystallographic planes (perpendicular to the [002] axis). 
$\mathrm{VOPO}_{4} \cdot 2 \mathrm{H}_{2} \mathrm{O}$

a)

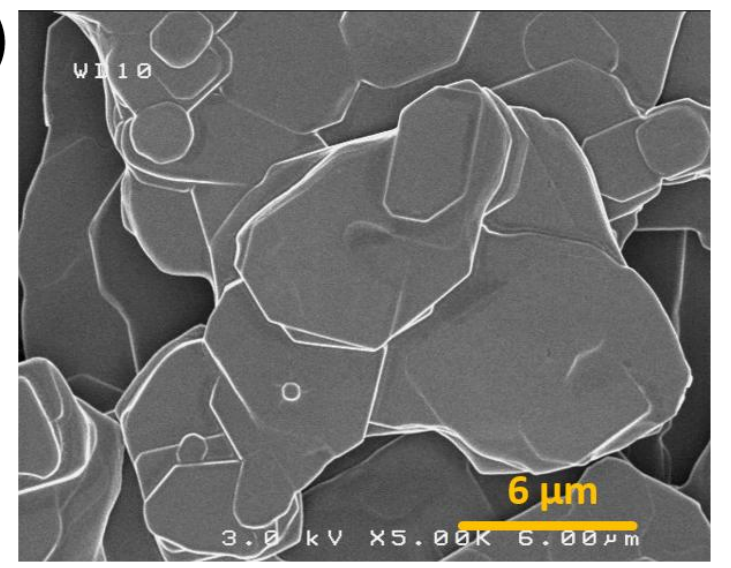

b)

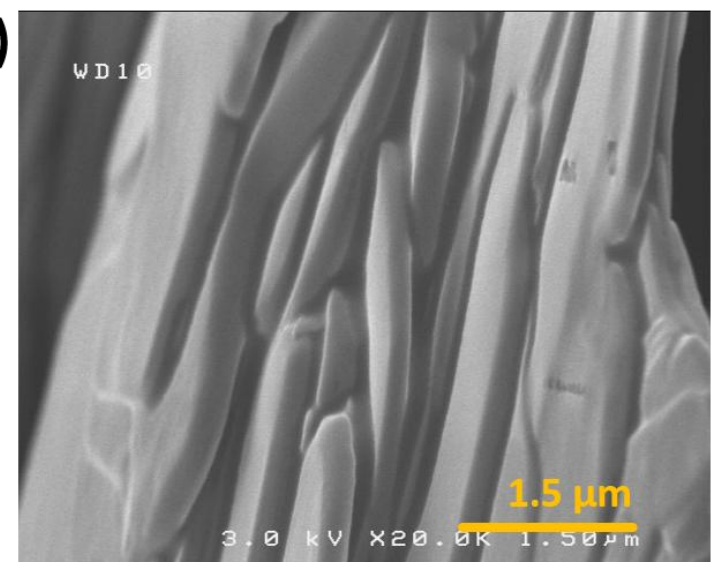

$\mathrm{NVPFO}_{2}$-ionothermal

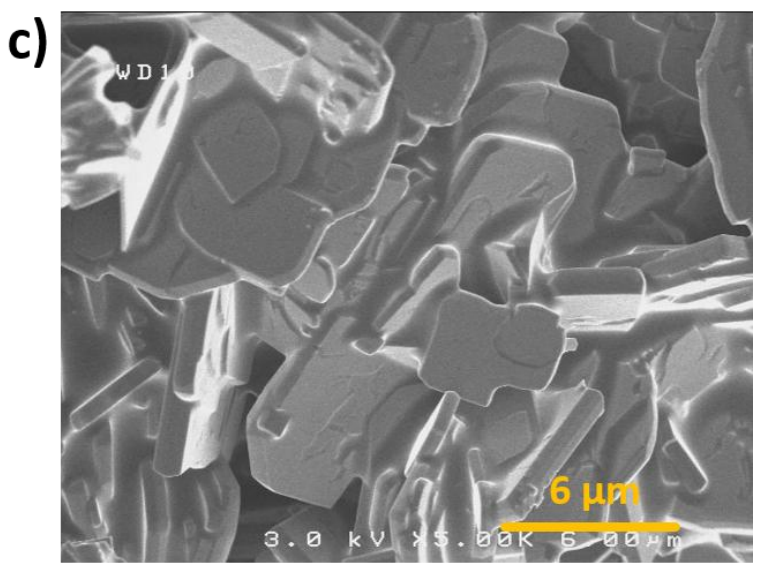

d)

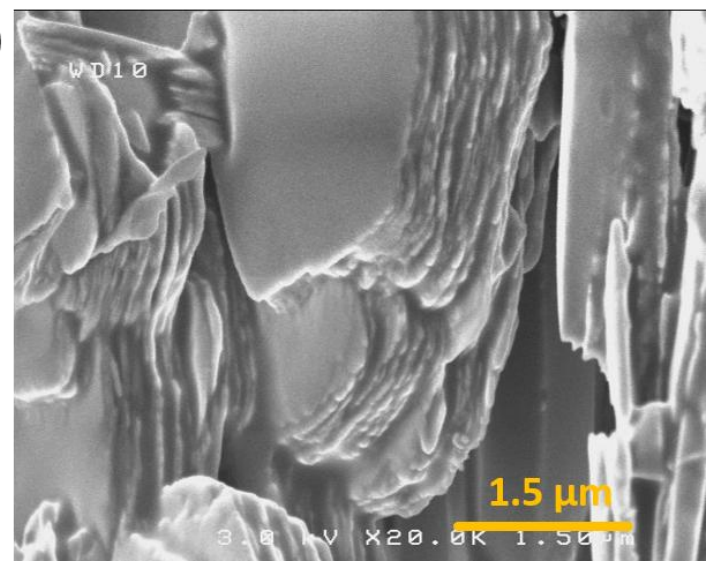

Figure 2. SEM images of the $\alpha-V O P O_{4} \cdot 2 \mathrm{H}_{2} \mathrm{O}$ precursor $(a-b)$ and $\mathrm{NVPFO} \mathrm{O}_{2}$ obtained in ionothermal conditions $(c-d)$.

In order to get more insight into the origin of this preferential orientation, SEM images were taken to compare the morphology of the $\alpha-\mathrm{VOPO}_{4} \cdot 2 \mathrm{H}_{2} \mathrm{O}$ precursor and that of the as-prepared $\mathrm{Na}_{3} \mathrm{~V}_{2}\left(\mathrm{PO}_{4}\right)_{2} \mathrm{FO}_{2}$ (Figure 2). Both compounds are characterized by a platelet-like morphology. The platelets observed for $\alpha-\mathrm{VOPO}_{4} \cdot 2 \mathrm{H}_{2} \mathrm{O}$ are polydispersed, with their size ranging from several hundred nanometers to ten micrometers in length (Figure 2a), and 100$200 \mathrm{~nm}$ in thickness (Figure 2b). The platelets observed for $\mathrm{NVPFO}_{2}$ appear to be also polydispersed, and the size of their primary particles is similar to those of $\alpha-\mathrm{VOPO}_{4} \cdot 2 \mathrm{H}_{2} \mathrm{O}$ (Figure 2c); however, they seem to be thicker with etched edges (Figure 2d). Based on these $\mathrm{XRD}$ and SEM data, it can be deduced that $\mathrm{NVPFO}_{2}$ obtained by ionothermal synthesis is composed of several platelets and the plane of each platelet corresponding to the $(a b)$ crystallographic plane of $\mathrm{NVPFO}_{2}$, which explains the intense (002) reflection (Figure 1). This particular platelet morphology is entirely different from that of $\mathrm{NVPFO}_{2}$ obtained by solid-state synthesis, which has no particular shape (Figure S3). It is also interesting to note 
that the $\mathrm{Na}^{+}$diffusion channels of $\mathrm{Na}_{3} \mathrm{~V}_{2}\left(\mathrm{PO}_{4}\right)_{2} \mathrm{FO}_{2}$ are also situated in this $(a b)$ plane, as described in Figure 4b.

a)

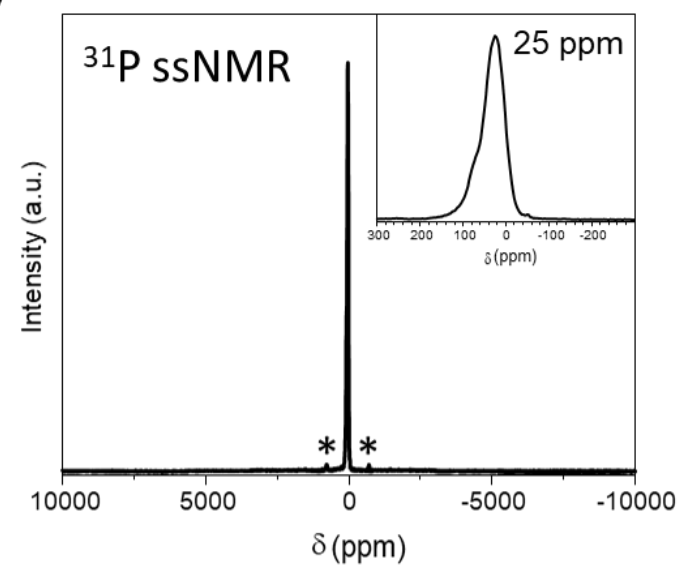

b)

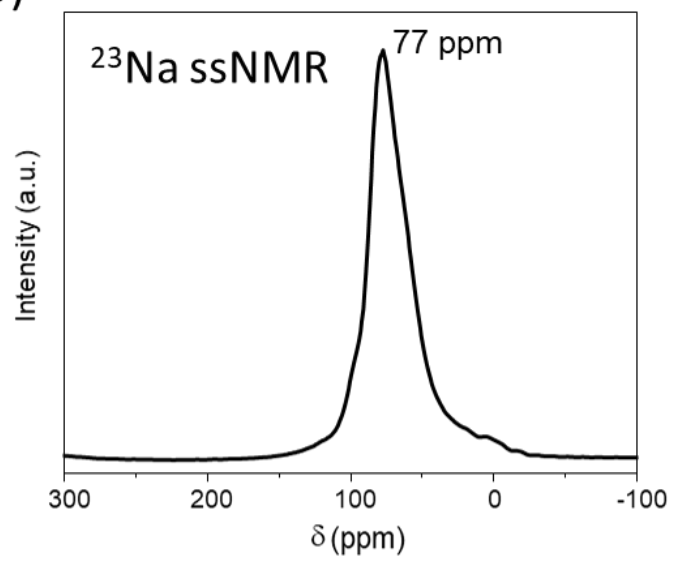

c)

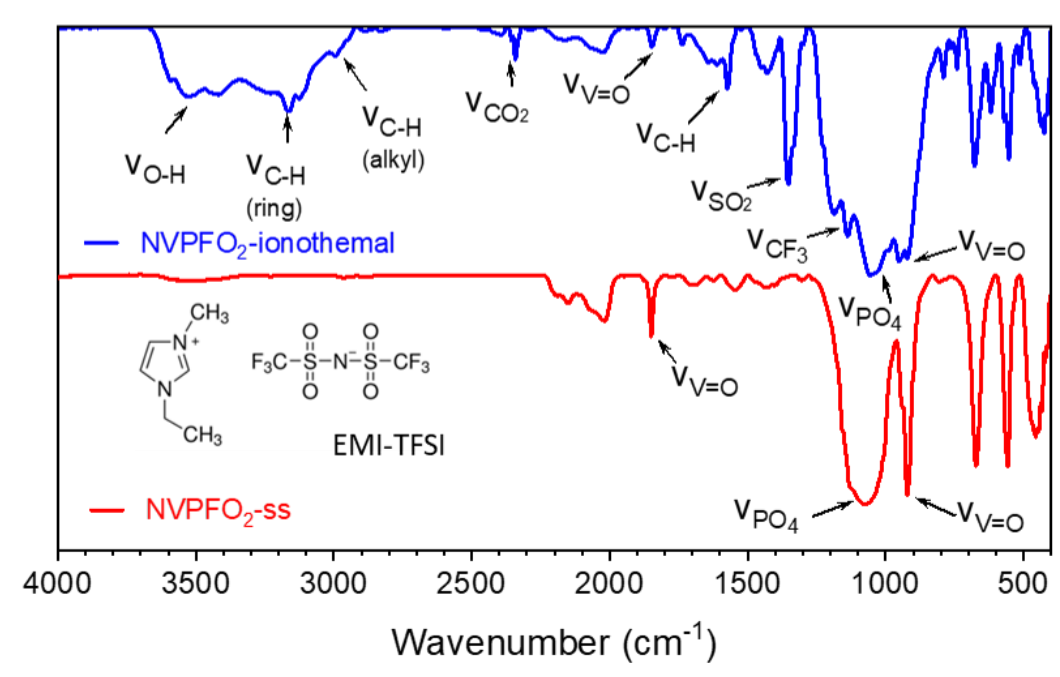

Figure 3. a) ${ }^{31} \mathrm{P}$ ss-NMR spectrum of $\mathrm{NVPFO}_{2}$-iono recorded at $\mathrm{B}_{0}=2.35 \mathrm{~T}$ with $\mathrm{MAS}$ frequency $=30$ $\mathrm{kHz}$. The asterisks indicate the spinning sidebands $b)^{23} \mathrm{Na}$ ss-NMR spectrum of $\mathrm{NVPFO}_{2}$-iono collected at $B_{0}=11.7 \mathrm{~T}$ with MAS frequency $=30 \mathrm{kHz} . \mathrm{c}$ ) Comparison of the IR spectra recorded between 400 and $4000 \mathrm{~cm}^{-1}$ for $\mathrm{NVPFO}_{2}$ samples obtained by the ionothermal approach (blue) and by a solid-state reaction at high temperature (red).

The ${ }^{31} \mathrm{P}$ ss-NMR spectrum recorded for $\mathrm{NVPFO}_{2}$ obtained from the ionothermal approach shows an intense diamagnetic signal with an isotropic shift $\left(\delta_{\text {iso }}\right)$ located at $\sim 25 \mathrm{ppm}$ and attributed to the $\mathrm{P}\left(\mathrm{OV}^{4+}\right)_{4}$ local environment (Figure 3a). ${ }^{12,42}$ The absence of paramagnetic resonances at $\sim 1500 \mathrm{ppm}, 3000 \mathrm{ppm}, 4500 \mathrm{ppm}$, or $6000 \mathrm{ppm}$ excludes the presence of any trivalent vanadium and thus supports the $\mathrm{Na}_{3} \mathrm{~V}^{4+}{ }_{2}\left(\mathrm{PO}_{4}\right)_{2} \mathrm{FO}_{2}$ formula. ${ }^{42}$ The ${ }^{31} \mathrm{P}$ ss-NMR signal also shows a minor contribution at $85 \mathrm{ppm}$, which could be assigned to ${ }^{31} \mathrm{P}$ nuclei in 
$\mathrm{Na}_{0.5} \mathrm{VOPO}_{4} \cdot 2 \mathrm{H}_{2} \mathrm{O}$. The ${ }^{23} \mathrm{Na}$ ss-NMR spectrum of $\mathrm{NVPFO}_{2}$-iono exhibits a broad signal located at $77 \mathrm{ppm}$ corresponding to the $\mathrm{Na}\left(\mathrm{OV}^{4+}\right)_{2}$ environment, as expected for $\mathrm{NVPFO}_{2}$ (Figure 3b). ${ }^{4,42}$ Once again, the absence of the signals at higher isotropic shifts excludes the presence of any $\mathrm{V}^{3+}$ in this phase. ${ }^{4,42-44}$

A comparison of the IR spectra of $\mathrm{NVPFO}_{2}$ powder obtained by a solid-state reaction at high temperature and by ionothermal reaction is given in Figure 3c. Both IR spectra show vibrational bands at $925 \mathrm{~cm}^{-1}$ (with an overtone at $1850 \mathrm{~cm}^{-1}$ ) and $1080 \mathrm{~cm}^{-1}$, attributed to the stretching modes of vanadyl and phosphate groups, respectively. ${ }^{45}$ In the case of $\mathrm{NVPFO}_{2}$ iono, additional bands are observed at $\sim 3000-3200,1350$, and $1140 \mathrm{~cm}^{-1}$, and they are attributed to the respective vibrations of $\mathrm{C}-\mathrm{H}$ bonds in the imidazolium ring, $\mathrm{SO}_{2}$ groups, and $\mathrm{CF}_{3}$ groups, which explicitly demonstrate the presence of EMI-TFSI ionic liquid on the material's surface. ${ }^{46,47}$ The latter should be present in very low amounts and/or in the amorphous state as it is not detected by X-ray diffraction, which is consistent with a surface modification.

\subsection{Topochemical considerations}

The structure of $\alpha-\mathrm{VOPO}_{4} \cdot 2 \mathrm{H}_{2} \mathrm{O}$ is characterized by vanadyl phosphate layers separated by water molecules (Figure 4a). Each vanadium ion in the structure is in the $\mathrm{V}^{5+}$ state and is surrounded by six oxygen to form a distorted octahedron with four oxygens in the equatorial square plan belonging also to neighboring phosphate groups $\left(d_{V-O}=\sim 1.90 \AA\right)$. The coordination with one of the oxygen in the apical position along the $c$-axis forms a vanadyl bond $(1.57 \AA)$, whereas the other $\mathrm{V}-\mathrm{O}$ axial bond involves a water molecule. The vanadyl bonds in $\alpha$-VOPO $4 \cdot 2 \mathrm{H}_{2} \mathrm{O}$ are pointing upward or downward alternatively along the $c$ direction. There are two different kinds of water molecules in the structure: one belongs to the vanadium octahedra, whereas the other is a "free" water molecule locating in the interlayer space and creating the H-bridges either with the upper or lower phosphate oxygens (blue plane in Figure 4a). ${ }^{48}$ On the other hand, the structure of $\mathrm{Na}_{3} \mathrm{~V}_{2}\left(\mathrm{PO}_{4}\right)_{2} \mathrm{FO}_{2}$ is built by the interconnection between vanadium bi-octahedral units, $\mathrm{O}=\mathrm{V}^{4+} \mathrm{O}_{4}-\mathrm{F}-\mathrm{O}_{4} \mathrm{~V}^{4+}=\mathrm{O}$, linked together by phosphate groups to form a 3D framework (Figure 4b). Each bi-octahedron consists of two $\mathrm{O}=\mathrm{V}^{4+} \mathrm{O}_{4} \mathrm{~F}$ sub-octahedra sharing a common fluorine atom, and the position opposite to this bridging $\mathrm{V}-\mathrm{F}$ bond is occupied by a short and covalent vanadyl bond (1.62 $\AA)$. The other positions in the sub-octahedron are occupied by four oxygen atoms $\left(d_{\mathrm{V}-\mathrm{O}}=\sim 2.0\right.$ 
A), forming a square plane. ${ }^{9}$ The relatively mobile sodium ions are localized in the channels in the crystallographic planes at $z=0$ and $1 / 2$.

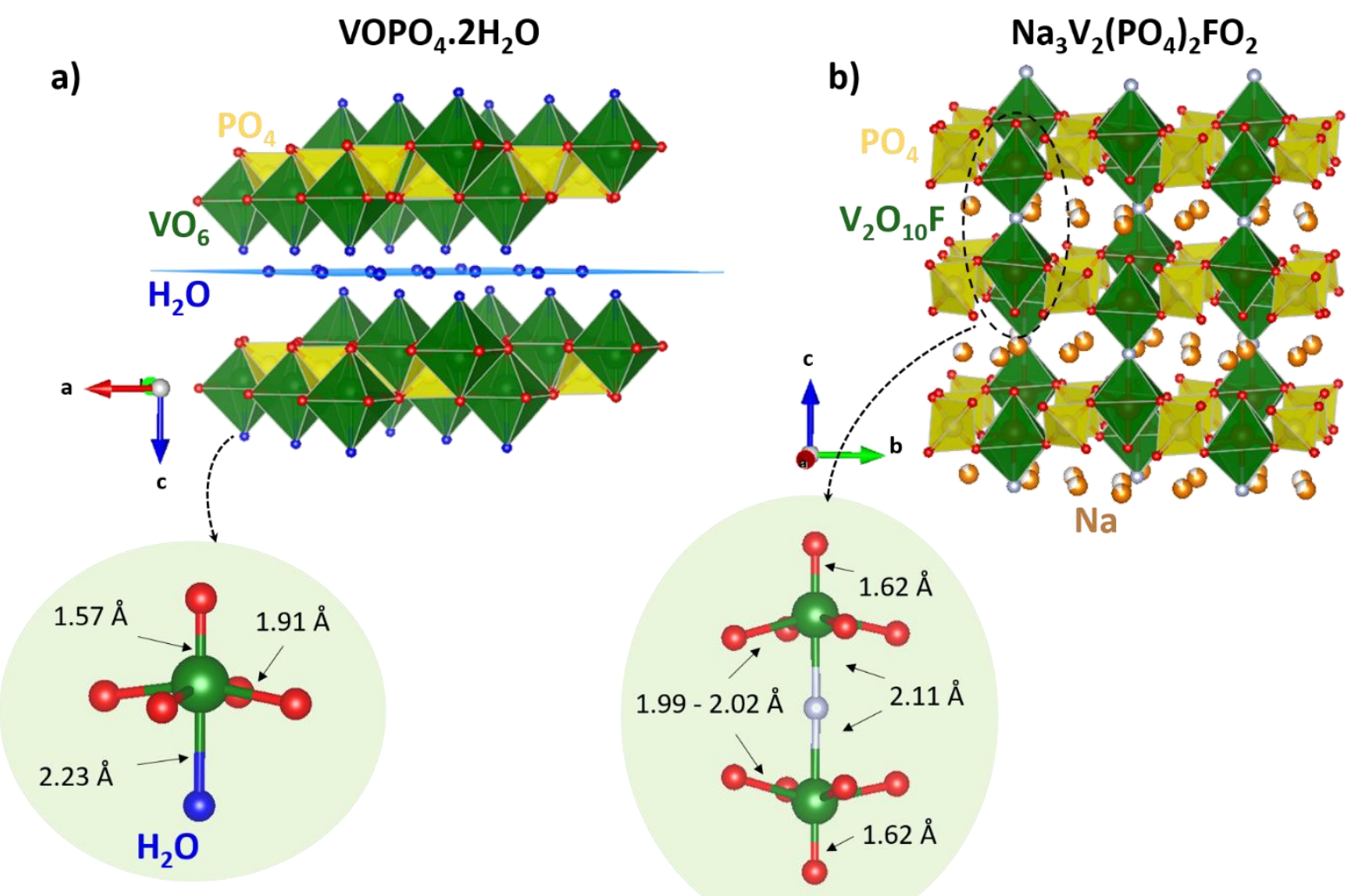

Figure 4. Crystal structure representation of a) $\alpha-V O P O_{4} \cdot 2 \mathrm{H}_{2} \mathrm{O}$ and b) $\mathrm{Na}_{3} \mathrm{~V}_{2}\left(\mathrm{PO}_{4}\right)_{2} \mathrm{FO}_{2} \cdot \mathrm{VO}_{6}$ or $\mathrm{VO}_{5} \mathrm{~F}$ octahedra and $\mathrm{PO}_{4}$ tetrahedra are depicted as green and yellow polyhedra, respectively. Blue spheres correspond to water molecules, and the light blue plan highlights the position of "free" water molecules in between the vanadyl phosphate layers. Na ions are represented as brownish spheres.

Despite a difference in their dimensionality, $\alpha-\mathrm{VOPO}_{4} \cdot 2 \mathrm{H}_{2} \mathrm{O}(2 \mathrm{D})$ and $\mathrm{Na}_{3} \mathrm{~V}_{2}\left(\mathrm{PO}_{4}\right)_{2} \mathrm{FO}_{2}$ (3D) present similar building blocks with an alternate sequence of phosphate and vanadyl polyhedra in the $(a b)$ plane as described in Figure 5 and we, therefore, propose that $\mathrm{Na}_{3} \mathrm{~V}_{2}\left(\mathrm{PO}_{4}\right)_{2} \mathrm{FO}_{2}$ obtained in ionothermal conditions can be synthesized from $\alpha-\mathrm{VOPO}_{4} \cdot 2 \mathrm{H}_{2} \mathrm{O}$ via a topochemical reaction. Upon increasing temperature, the dehydration process, which probably starts with the water molecules in the interlayer space of $\alpha-\mathrm{VOPO}_{4} \cdot 2 \mathrm{H}_{2} \mathrm{O}$ (Figure S4), will destabilize the interaction between the vanadyl phosphate layers, and thus promote the insertion of $\mathrm{Na}^{+}$and $\mathrm{F}^{-}$ions into the structure. During this process, $\mathrm{F}^{-}$anions will replace the water molecules involved in the vanadium octahedral coordination sphere while charge compensation occurs through the inclusion of $\mathrm{Na}^{+}$. Such a topochemical reaction was also observed for the ionothermal synthesis of $\mathrm{LiFeSO}_{4} \mathrm{~F}$, starting from $\mathrm{FeSO}_{4} \cdot \mathrm{H}_{2} \mathrm{O}{ }^{34}$ During the 
reaction between $\alpha-\mathrm{VOPO}_{4} \cdot 2 \mathrm{H}_{2} \mathrm{O}$ and $\mathrm{NaF}, \mathrm{V}^{5+}$ ions are most likely reduced into $\mathrm{V}^{4+}$ by the imidazolium cation of the EMI-TFSI molecule at moderated temperature, and this reduction process further promotes the $\mathrm{Na}^{+}$uptake into the structure. ${ }^{49}$ During the topotactic reaction, the gliding of vanadyl phosphate layers in the $(a b)$ plane occurs simultaneously with a crosslinking process through the formation of covalent $\mathrm{V}-\mathrm{F}$ bonds, leading to the generation of $\mathrm{O}=\mathrm{V}^{4+} \mathrm{O}_{4}-\mathrm{F}-\mathrm{O}_{4} \mathrm{~V}^{4+}=\mathrm{O}$ bi-octahedral units, and thus of a stable 3D framework (Figure 6). Furthermore, the dehydrated water molecules from $\alpha-\mathrm{VOPO}_{4} \cdot 2 \mathrm{H}_{2} \mathrm{O}$ can partially hydrolyze the unreacted $\mathrm{F}^{-}$ions to form hydrofluoric acid (HF). This acid is corrosive and can attack the newly formed $\mathrm{Na}_{3} \mathrm{~V}_{2}\left(\mathrm{PO}_{4}\right) \mathrm{FO}_{2}$, which results in the etched platelets (Figure 2d). The anisotropy of line broadening that appears for $\mathrm{Na}_{3} \mathrm{~V}_{2}\left(\mathrm{PO}_{4}\right) \mathrm{FO}_{2}$ (especially for (002) reflection, Figure 1), whereas it is absent for the precursor, further supports the topochemical mechanism and could be due to a micro-stress/strain occurring during the stacking of $\mathrm{VOPO}_{4}$.

a)

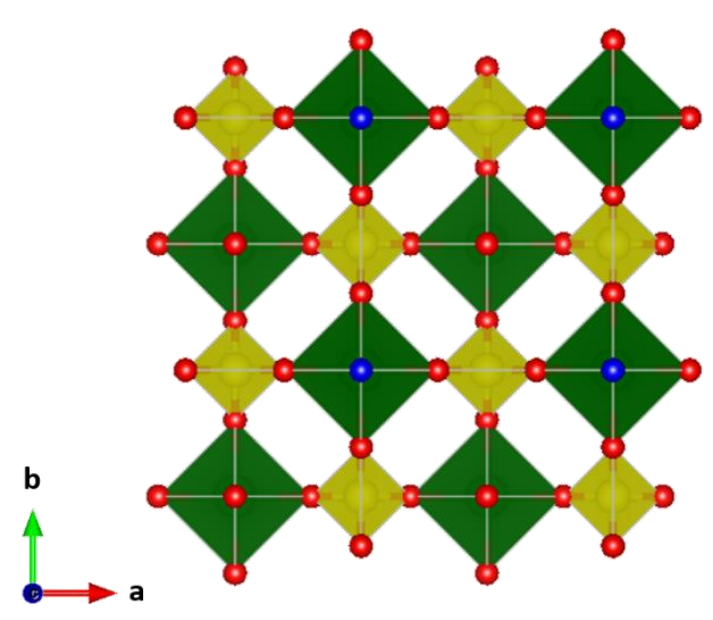

b)

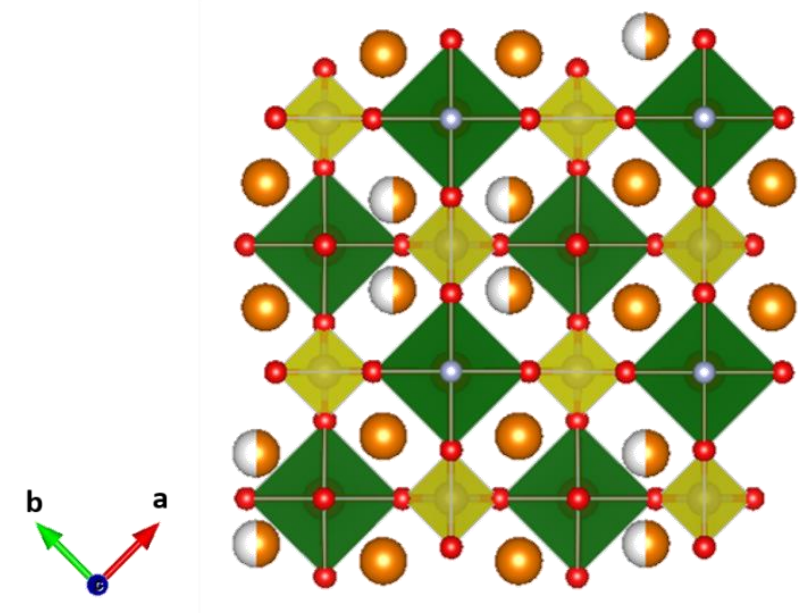

Figure 5. Structural projection in the (ab) plane of a) $\alpha-\mathrm{VOPO}_{4} \cdot 2 \mathrm{H}_{2} \mathrm{O}$ and $b$ ) $\mathrm{Na}_{3} \mathrm{~V}_{2}\left(\mathrm{PO}_{4}\right)_{2} \mathrm{FO}_{2}$. For $\alpha-\mathrm{VOPO}_{4} \cdot 2 \mathrm{H}_{2} \mathrm{O}, \mathrm{PO}_{4}$ and $\mathrm{O}=\mathrm{VO}_{4}-\mathrm{O}$ groups are depicted as yellow and green polyhedra, respectively. Oxygen anions that belong to water molecules are represented in blue. For $\mathrm{Na}_{3} \mathrm{~V}_{2}\left(\mathrm{PO}_{4}\right)_{2} \mathrm{FO}_{2}, \mathrm{PO}_{4}$ and $\mathrm{O}=\mathrm{VO}_{4} \mathrm{~F}$ groups are depicted as yellow and green polyhedra, respectively. $\mathrm{Na}^{+}$ions are represented by brownish spheres. 


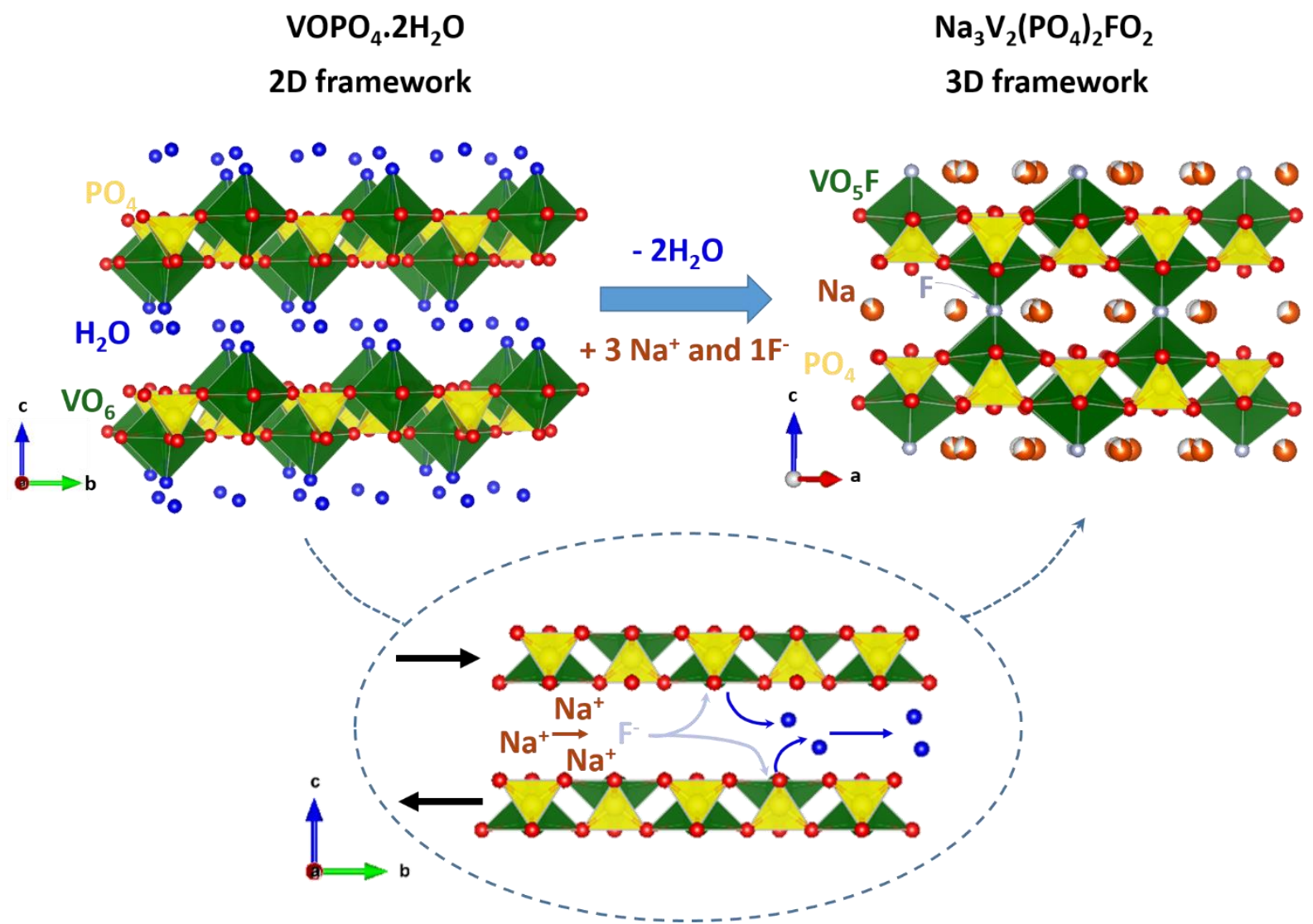

Figure 6. Representation of a possible topochemical formation mechanism starting from $2 D \alpha$ $\mathrm{VOPO}_{4} \cdot 2 \mathrm{H}_{2} \mathrm{O}$ and $\mathrm{NaF}$, leading to $3 \mathrm{D} \mathrm{Na}_{3} \mathrm{~V}_{2}\left(\mathrm{PO}_{4}\right) \mathrm{FO}_{2}$.

\subsection{Electrochemical properties}

Figure 7a shows the two first galvanostatic charge/discharge cycles of a Na//NVPFO ${ }_{2}$ halfcell operating at $C / 20$ in the potential range $2.5-4.5 \mathrm{~V}$ vs. $\mathrm{Na} / \mathrm{Na}^{+}$. The voltage-composition profile of $\mathrm{NVPFO}_{2}$-iono is characterized by two reversible "pseudo-plateaus" at around $3.6 \mathrm{~V}$ and 4.0 V vs $\mathrm{Na}^{+} / \mathrm{Na}$, which are typical of sodium vanadium oxyfluorophosphate materials. ${ }^{9,14,16}$ In the case of $\mathrm{Na}_{3} \mathrm{~V}_{2}\left(\mathrm{PO}_{4}\right)_{2} \mathrm{FO}_{2}$, the electrochemical reaction is associated with the activation of $\{\mathrm{V}=\mathrm{O}\}^{3+} /\{\mathrm{V}=\mathrm{O}\}^{2+}$ redox couple, which is also written as $\mathrm{V}^{5+} / \mathrm{V}^{4+} .6,9$ 
a)

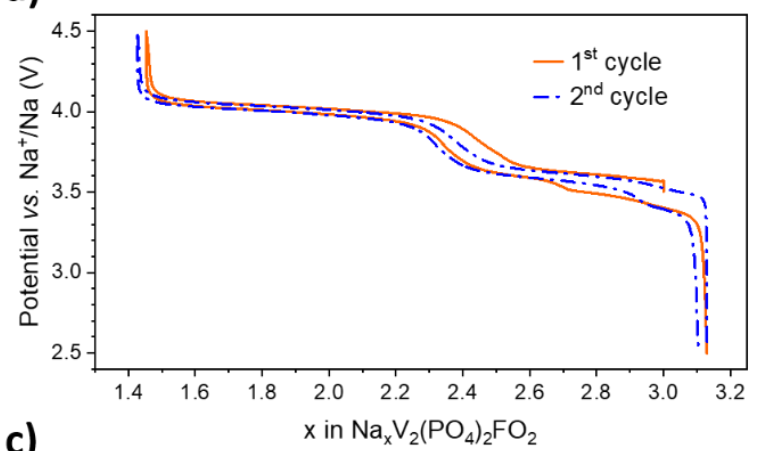

c)

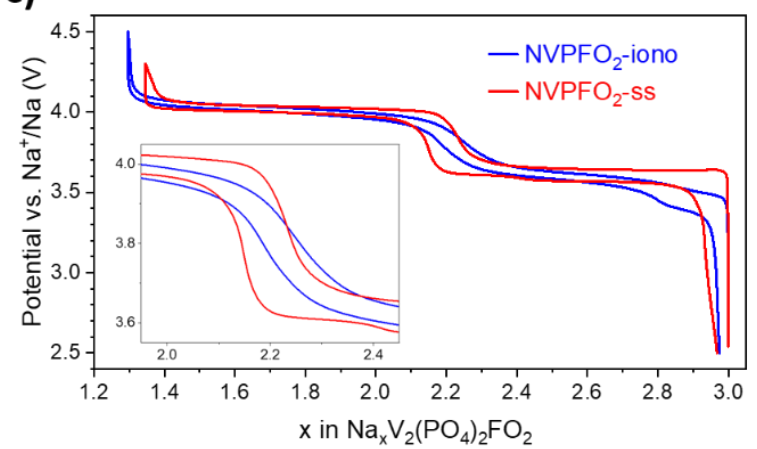

b)

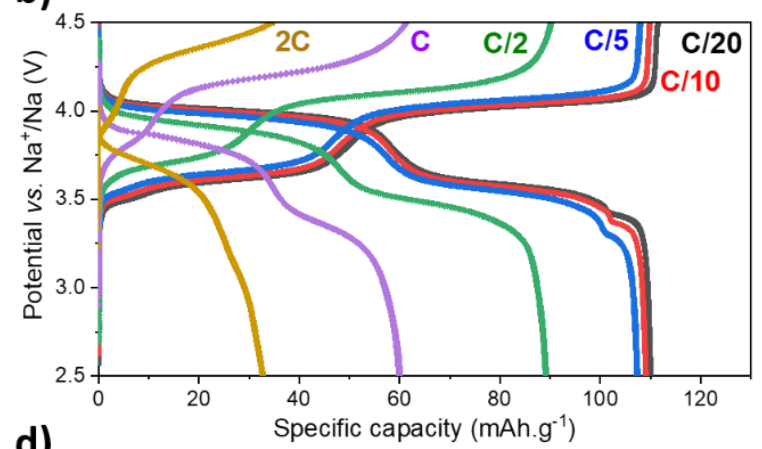

d)

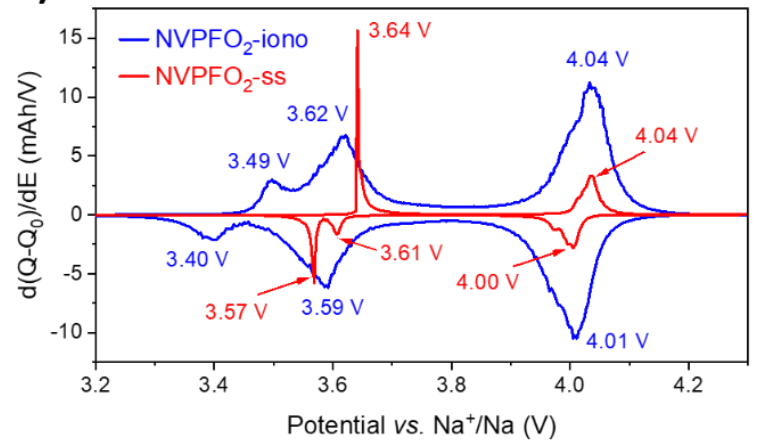

Figure 7. a) Charge/discharge profiles of a $\mathrm{Na} / / \mathrm{Na}_{3} \mathrm{~V}_{2}\left(\mathrm{PO}_{4}\right)_{2} \mathrm{FO}_{2}$-iono half-cell operating at $\mathrm{C} / 2 \mathrm{O}$ in the potential range 2.5-4.5 Vvs Na/Na+ . b) Galvanostatic charge-discharge profiles and specific capacity obtained at different cycling rates. c) Comparison between the $2^{\text {nd }}$ cycle of Nal/NVPFO-iono (blue curve) and $\mathrm{Na} / / \mathrm{NVPFO}_{2}$-ss (red curve) in half-cells operating at C/20. The inset represents an enlargement around the potential jump, between the two "pseudo plateaus". d) First derivative curves of the electrochemical plots given in c).

In the first charge-discharge cycle, the discharge capacity is slightly greater than the charge one (Figure 7a and S5) because of the extra capacity provided by the $\mathrm{Na}_{0.5} \mathrm{VOPO}_{4} \cdot 2 \mathrm{H}_{2} \mathrm{O}$ impurity, which represents $7 \%$ of the total capacity. ${ }^{50,51}$ Figure $7 \mathbf{c}$ compares the second galvanostatic cycle of $\mathrm{NVPFO}_{2}$ obtained by the ionothermal approach ( $\mathrm{NVPFO}_{2}$-iono in blue) and by solid-state synthesis ( $\mathrm{NVPFO}_{2}$-ss in red), performed at $\mathrm{C} / 20 \mathrm{vs} \mathrm{Na}$ metal. Although the materials are not carbon-coated, both exhibit very low polarization indicating a good diffusion process of $\mathrm{Na}^{+}$ions within the materials and the electrodes. However, the transition between the two "pseudo-plateaus" is much smoother for $\mathrm{NVPFO}_{2}$-iono than for $\mathrm{NVPFO}_{2}$-ss (Inset in Figure 7c), in good agreement with more sloping electrochemical profiles (broader peaks observed on the corresponding derivative curves (Figure 7d)) for the $\mathrm{NVPFO}_{2}$-iono material. This peculiar electrochemical profile, observed for $\mathrm{NVPFO}_{2}$-iono, suggests that $\mathrm{Na}^{+}$ deintercalation occurs through a solid solution mechanism when the material is obtained as platelets, whereas successive biphasic reactions occurs for $\mathrm{NVPFO}_{2}$-ss. Some recent studies have demonstrated that the electrochemical mechanisms of $\mathrm{Na}_{3} \mathrm{~V}_{2}\left(\mathrm{PO}_{4}\right)_{2} \mathrm{FO}_{2}$ can be 
modulated by partial cationic and/or anionic substitutions of $\mathrm{V}$ by $\mathrm{Al} / \mathrm{Fe}$ or $\mathrm{O}$ by $\mathrm{F}$; however, changes in the morphology of $\mathrm{Na}_{3} \mathrm{~V}_{2}\left(\mathrm{PO}_{4}\right)_{2} \mathrm{FO}_{2}$ could also have an impact as observed in this study. ${ }^{9,12,52}$ Concerning the energy storage performances, $\mathrm{NVPFO}_{2}$-iono exhibits a high specific capacity of $110 \mathrm{mAh} \cdot \mathrm{g}^{-1}$ at $C / 20$ and excellent capacity retention at moderated current densities (107 mAh.g $\mathrm{g}^{-1}$ at $\mathrm{C} / 5$ and $88 \mathrm{mAh} \cdot \mathrm{g}^{-1}$ at $\left.\mathrm{C} / 2\right)$, which are better than those obtained for $\mathrm{NVPFO}_{2}$-ss (Figure 7b and S6), and even better or comparable to those of non-coated $\mathrm{Na}_{3} \mathrm{~V}^{3+}{ }_{2-y} \mathrm{~V}^{4+}{ }_{y}\left(\mathrm{PO}_{4}\right)_{2} \mathrm{~F}_{3-y} \mathrm{O}_{y}$ materials reported in the literature (Table S1). ${ }^{20,21,53-59}$ Two phenomena could promote this good capacity retention. First, the platelet morphology, corresponding to the $(a b)$ crystallographic plane of $\mathrm{Na}_{3} \mathrm{~V}_{2}\left(\mathrm{PO}_{4}\right)_{2} \mathrm{FO}_{2}$, is probably favoring fast $\mathrm{Na}^{+}$diffusion in the channels localized in the same plane. Then, the presence of conductive ionic liquid on the surface of $\mathrm{NVPFO}_{2}$, as highlighted by IR, could also improve sodium diffusion at high cycling rates. Indeed, better diffusion kinetics upon cycling has already been observed for $\mathrm{Co}(\mathrm{OH})_{2}$ used as positive electrode for hybrid supercapacitors when its surface was functionalized by ILs. ${ }^{36,39}$

\section{Conclusion}

A new experimental approach based on ionothermal synthesis is reported in this work, which can be used to synthesize $\mathrm{Na}_{3} \mathrm{~V}_{2}\left(\mathrm{PO}_{4}\right)_{2} \mathrm{FO}_{2}$ particles with a $2 \mathrm{D}$ morphology. This peculiar morphology is explained by a topochemical reaction, which involves dehydration, layer gliding, insertion of $\mathrm{Na}^{+}$and $\mathrm{F}^{-}$into the interlayer space, reduction of $\mathrm{V}^{5+}$ to $\mathrm{V}^{4+}$ compensated by $\mathrm{Na}^{+}$intercalation, and cross-linking process through the formation of $\mathrm{V}-\mathrm{F}$ bonds. The combination of XRD and NMR analyses excluded the presence of $\mathrm{V}^{3+}$ in the structure and validated the preparation of the $\mathrm{V}^{4+}$ only composition $\mathrm{Na}_{3} \mathrm{~V}^{4+}{ }_{2}\left(\mathrm{PO}_{4}\right)_{2} \mathrm{FO}_{2}$. This $\mathrm{Na}_{3} \mathrm{~V}_{2}\left(\mathrm{PO}_{4}\right)_{2} \mathrm{FO}_{2}$ sample with the platelet morphology obtained by ionothermal reaction behaves differently from that obtained by conventional solid-state reaction and suggests a monophasic $\mathrm{Na}^{+}$insertion/extraction mechanism observed upon cycling, whereas a biphasic mechanism was expected. This different voltage-composition profile also leads to a smoother potential jump between the two "pseudo-plateaus", which is more interesting for application purposes. The presence of IL on the material electrode surface, the favorable orientation of platelets versus $\mathrm{Na}^{+}$diffusion, and the one-phase reaction mechanism can improve the ionic diffusion and increase capacity retention at high cycling rates. Last but not least, this work highlights the importance of developing new synthesis approaches in order to optimize the structure and the performance of battery materials. 


\section{Associated content:}

The Supporting Information is available free of charge.

XRD pattern of $\alpha-\mathrm{VOPO}_{4} \cdot 2 \mathrm{H}_{2} \mathrm{O}$; XRD patterns of $\mathrm{NVPFO}_{2}$-iono and $\mathrm{NVPFO}_{2}$-ss; SEM images; thermogravimetric analysis of $\alpha-\mathrm{VOPO}_{4} \cdot 2 \mathrm{H}_{2} \mathrm{O}$; galvanostatic charge/discharge curves of $\mathrm{NVPFO}_{2}$-iono; specific capacities of $\mathrm{NVPFO}_{2}$-iono and $\mathrm{NVPFO}_{2}$-ss at different current densities; table for comparison with literature.

Author Contributions: The manuscript was written through contributions of all authors. All authors have given approval to the final version of the manuscript

Notes : The authors declare no competing financial interest.

\section{Acknowledgements:}

This research receives the financial support from Région Nouvelle Aquitaine, the French National Research Agency through the funding "STORE-EX Labex Project ANR-10-LABX76-01" and the European Union's Horizon 2020 research and innovation program under grant agreement No 875629 (NAIMA). L.H.B.N. acknowledges the French RS2E Network for having financed his Ph.D research. The authors also want to thank Cathy DENAGE, Jérome KALISKY, Mathieu DUTTINE and Eric LEBRAUD (ICMCB) for their help with SEM, TGA, NMR and XRD, respectively. 


\section{References:}

(1) Hu, Y.; Komaba, S.; Forsyth, M.; Johnson, C.; Rojo, T. A New Emerging Technology: Na- Ion Batteries. Small Methods 2019, 3 (4), 1900184. https://doi.org/10.1002/smtd.201900184.

(2) Tarascon, J. Na-Ion versus Li-Ion Batteries: Complementarity Rather than Competitiveness. Joule 2020, 1-5. https://doi.org/10.1016/j.joule.2020.06.003.

(3) Broux, T.; Fauth, F.; Hall, N.; Chatillon, Y.; Bianchini, M.; Bamine, T.; Leriche, J.-B.; Suard, E.; Carlier, D.; Reynier, Y.; et al. High Rate Performance for Carbon- Coated $\mathrm{Na}_{3} \mathrm{~V}_{2}\left(\mathrm{PO}_{4}\right)_{2} \mathrm{~F}_{3}$ in Na- Ion Batteries. Small Methods 2019, 3 (4), 1800215. https://doi.org/10.1002/smtd.201800215.

(4) Serras, P.; Palomares, V.; Alonso, J.; Sharma, N.; López del Amo, J. M.; Kubiak, P.; Fdez-Gubieda, M. L.; Rojo, T. Electrochemical Na Extraction/Insertion of $\mathrm{Na}_{3} \mathrm{~V}_{2} \mathrm{O}_{2 \mathrm{x}}\left(\mathrm{PO}_{4}\right)_{2} \mathrm{~F}_{3-2}$. Chem. Mater. 2013, 25 (24), 4917-4925. https://doi.org/10.1021/cm403679b.

(5) Yan, G.; Dugas, R.; Tarascon, J.-M. The $\mathrm{Na}_{3} \mathrm{~V}_{2}\left(\mathrm{PO}_{4}\right)_{2} \mathrm{~F}_{3} /$ Carbon Na-Ion Battery: Its Performance Understanding as Deduced from Differential Voltage Analysis. J. Electrochem. Soc. 2018, 165 (2), A220-A227. https://doi.org/10.1149/2.0831802jes.

(6) Qi, Y.; Tong, Z.; Zhao, J.; Ma, L.; Wu, T.; Liu, H.; Yang, C.; Lu, J.; Hu, Y.-S. Scalable RoomTemperature Synthesis of Multi-Shelled $\mathrm{Na}_{3}\left(\mathrm{VOPO}_{4}\right)_{2} \mathrm{~F}$ Microsphere Cathodes. Joule 2018, 3, 1-16. https://doi.org/10.1016/j.joule.2018.07.027.

(7) Bianchini, M.; Xiao, P.; Wang, Y.; Ceder, G. Additional Sodium Insertion into Polyanionic Cathodes for Higher-Energy Na-Ion Batteries. Adv. Energy Mater. 2017, 7 (18), 1700514. https://doi.org/10.1002/aenm.201700514.

(8) Park, Y.-U.; Seo, D.-H.; Kim, H.; Kim, J.; Lee, S.; Kim, B.; Kang, K. A Family of High-Performance Cathode Materials for Na-Ion Batteries, $\mathrm{Na}_{3}\left(\mathrm{VO}_{1-\mathrm{x}} \mathrm{PO}_{4}\right)_{2} \mathrm{~F}_{1+2 \mathrm{x}}(0 \leq \mathrm{x} \leq 1)$ : Combined First-Principles and Experimental Study. Adv. Funct. Mater. 2014, 24 (29), 4603-4614. https://doi.org/10.1002/adfm.201400561.

(9) Nguyen, L. H. B.; Broux, T.; Camacho, P. S.; Denux, D.; Bourgeois, L.; Belin, S.; Iadecola, A.; Fauth, F.; Carlier, D.; Olchowka, J.; et al. Stability in Water and Electrochemical Properties of the $\mathrm{Na}_{3} \mathrm{~V}_{2}\left(\mathrm{PO}_{4}\right)_{2} \mathrm{~F}_{3}-\mathrm{Na}_{3}(\mathrm{VO})_{2}\left(\mathrm{PO}_{4}\right)_{2} \mathrm{~F}$ Solid Solution. Energy Storage Mater. 2019, 20 (February), 324 334. https://doi.org/10.1016/j.ensm.2019.04.010.

(10) Broux, T.; Fleutot, B.; David, R.; Brüll, A.; Veber, P.; Fauth, F.; Courty, M.; Croguennec, L.; Masquelier, C. Temperature Dependence of Structural and Transport Properties for $\mathrm{Na}_{3} \mathrm{~V}_{2}\left(\mathrm{PO}_{4}\right)_{2} \mathrm{~F}_{3}$ and $\mathrm{Na}_{3} \mathrm{~V}_{2}\left(\mathrm{PO}_{4}\right)_{2} \mathrm{~F}_{2.5} \mathrm{O}_{0.5}$. Chem. Mater. 2018, 30 (2), 358-365. https://doi.org/10.1021/acs.chemmater.7b03529.

(11) Yan, G.; Mariyappan, S.; Rousse, G.; Jacquet, Q.; Deschamps, M.; David, R.; Mirvaux, B.; Freeland, J. W.; Tarascon, J.-M. Higher Energy and Safer Sodium Ion Batteries via an Electrochemically Made Disordered $\mathrm{Na}_{3} \mathrm{~V}_{2}\left(\mathrm{PO}_{4}\right)_{2} \mathrm{~F}_{3}$ Material. Nat. Commun. 2019, 10 (1), 585. https://doi.org/10.1038/s41467019-08359-y.

(12) Olchowka, J.; Nguyen, L. H. B.; Broux, T.; Sanz Camacho, P.; Petit, E.; Fauth, F.; Carlier, D.; Masquelier, C.; Croguennec, L. Aluminum Substitution for Vanadium in the $\mathrm{Na}_{3} \mathrm{~V}_{2}\left(\mathrm{PO}_{4}\right)_{2} \mathrm{~F}_{3}$ and $\mathrm{Na}_{3} \mathrm{~V}_{2}\left(\mathrm{PO}_{4}\right)_{2} \mathrm{FO}_{2}$ Type Materials. Chem. Commun. 2019, 55 (78), 11719-11722. https://doi.org/10.1039/C9CC05137F.

(13) Liu, Q.; Meng, X.; Wei, Z.; Wang, D.; Gao, Y.; Wei, Y.; Du, F.; Chen, G. Core/Double-Shell Structured $\mathrm{Na}_{3} \mathrm{~V}_{2}\left(\mathrm{PO}_{4}\right)_{2} \mathrm{~F}_{3} @ \mathrm{C}$ Nanocomposite as the High Power and Long Lifespan Cathode for Sodium-Ion Batteries. ACS Appl. Mater. Interfaces 2016, 8 (46), 31709-31715. https://doi.org/10.1021/acsami.6b11372.

(14) Shen, X.; Zhao, J.; Li, Y.; Sun, X.; Yang, C.; Liu, H.; Hu, Y.-S. Controlled Synthesis of $\mathrm{Na}_{3}\left(\mathrm{VOPO}_{4}\right)_{2} \mathrm{~F}$ Cathodes with an Ultralong Cycling Performance. ACS Appl. Energy Mater. 2019, 2, 7474-7482. https://doi.org/10.1021/acsaem.9b01458.

(15) Qi, Y.; Mu, L.; Zhao, J.; Hu, Y.-S.; Liu, H.; Dai, S. PH-Regulative Synthesis of $\mathrm{Na}_{3}\left(\mathrm{VPO}_{4}\right)_{2} \mathrm{~F}_{3}$ Nanoflowers and Their Improved Na Cycling Stability. J. Mater. Chem. A 2016, 4 (19), 7178-7184. 
https://doi.org/10.1039/C6TA01023G.

(16) Qi, Y.; Mu, L.; Zhao, J.; Hu, Y.-S.; Liu, H.; Dai, S. Superior Na-Storage Performance of LowTemperature-Synthesized $\mathrm{Na}_{3}\left(\mathrm{VO}_{1-\mathrm{x}} \mathrm{PO}_{4}\right)_{2} \mathrm{~F}_{1+2 \times}(0 \leq \mathrm{x} \leq 1)$ Nanoparticles for Na-Ion Batteries. Angew. Chemie Int. Ed. 2015, 54 (34), 9911-9916. https://doi.org/10.1002/anie.201503188.

(17) Qi, Y.; Zhao, J.; Yang, C.; Liu, H.; Hu, Y.-S. Comprehensive Studies on the Hydrothermal Strategy for the Synthesis of $\mathrm{Na}_{3}\left(\mathrm{VO}_{1-\mathrm{x}} \mathrm{PO}_{4}\right)_{2} \mathrm{~F}_{1+2 \mathrm{x}}(0 \leq \mathrm{x} \leq 1)$ and Their Na-Storage Performance . Small Methods 2018, 3, 1800111. https://doi.org/10.1002/smtd.201800111.

(18) Mukherjee, A.; Sharabani, T.; Perelshtein, I.; Noked, M. Three- Sodium Ion Activity of a Hollow Spherical $\mathrm{Na}_{3} \mathrm{~V}_{2}\left(\mathrm{PO}_{4}\right)_{2} \mathrm{~F}_{3}$ Cathode: Demonstrating High Capacity and Stability. Batter. Supercaps 2020, 3 (1), 52-55. https://doi.org/10.1002/batt.201900147.

(19) Yi, H.; Lin, L.; Ling, M.; Lv, Z.; Li, R.; Fu, Q.; Zhang, H.; Zheng, Q.; Li, X. Scalable and Economic Synthesis of High-Performance $\mathrm{Na}_{3} \mathrm{~V}_{2}\left(\mathrm{PO}_{4}\right)_{2} \mathrm{~F}_{3}$ by a Solvothermal-Ball-Milling Method. ACS Energy Lett. 2019, 4 (7), 1565-1571. https://doi.org/10.1021/acsenergylett.9b00748.

(20) Gu, Z.-Y.; Guo, J.-Z.; Sun, Z.-H.; Zhao, X.-X.; Li, W.-H.; Yang, X.-L.; Liang, H.-J.; Zhao, C.-D.; Wu, X.-L. Carbon-Coating-Increased Working Voltage and Energy Density towards an Advanced $\mathrm{Na}_{3} \mathrm{~V}_{2}\left(\mathrm{PO}_{4}\right)_{2} \mathrm{~F}_{3} @ \mathrm{C}$ Cathode in Sodium-Ion Batteries. Sci. Bull. 2020, 10 (43), 36851-36859. https://doi.org/10.1016/j.scib.2020.01.018.

(21) Nadeina, A.; Rozier, P.; Seznec, V. Facile Synthesis of a Common Na- Ion Battery Cathode Material $\mathrm{Na}_{3} \mathrm{~V}_{2}\left(\mathrm{PO}_{4}\right)_{2} \mathrm{~F}_{3}$ by Spark Plasma Sintering. Energy Technol. 2020, 165 (5), 1901304. https://doi.org/10.1002/ente.201901304.

(22) Eshraghi, N.; Caes, S.; Mahmoud, A.; Cloots, R.; Vertruyen, B.; Boschini, F. Sodium Vanadium (III) Fluorophosphate/Carbon Nanotubes Composite (NVPF/CNT) Prepared by Spray-Drying: Good Electrochemical Performance Thanks to Well-Dispersed CNT Network within NVPF Particles. Electrochim. Acta 2017, 228, 319-324. https://doi.org/10.1016/j.electacta.2017.01.026.

(23) Deng, G.; Chao, D.; Guo, Y.; Chen, Z.; Wang, H.; Savilov, S. V.; Lin, J.; Shen, Z. X. Graphene Quantum Dots-Shielded $\mathrm{Na}_{3}(\mathrm{VO})_{2}\left(\mathrm{PO}_{4}\right)_{2} \mathrm{~F} @ \mathrm{C}$ Nanocuboids as Robust Cathode for Na-Ion Battery. Energy Storage Mater. 2016, 5, 198-204. https://doi.org/10.1016/j.ensm.2016.07.007.

(24) Chao, D.; Lai, C.-H. M.; Liang, P.; Wei, Q.; Wang, Y.-S.; Zhu, C. R.; Deng, G.; Doan-Nguyen, V. V. T.; Lin, J.; Mai, L.; et al. Sodium Vanadium Fluorophosphates (NVOPF) Array Cathode Designed for HighRate Full Sodium Ion Storage Device. Adv. Energy Mater. 2018, 8 (16), 1800058. https://doi.org/10.1002/aenm.201800058.

(25) Qi, K.; Zheng, W. Morphology-Controlled Synthesis of Inorganic Nanocrystals by Ionic Liquid Assistance. Curr. Opin. Green Sustain. Chem. 2017, 5, 17-23. https://doi.org/10.1016/j.cogsc.2017.03.011.

(26) Morris, R. E. Ionothermal Synthesis-Ionic Liquids as Functional Solvents in the Preparation of Crystalline Materials. Chem. Commun. 2009, o (21), 2990. https://doi.org/10.1039/b902611h.

(27) MacFarlane, D. R.; Forsyth, M.; Howlett, P. C.; Kar, M.; Passerini, S.; Pringle, J. M.; Ohno, H.; Watanabe, M.; Yan, F.; Zheng, W.; et al. Ionic Liquids and Their Solid-State Analogues as Materials for Energy Generation and Storage. Nat. Rev. Mater. 2016, 1 (2), 15005. https://doi.org/10.1038/natrevmats.2015.5.

(28) Larcher, D.; Tarascon, J. M. Towards Greener and More Sustainable Batteries for Electrical Energy Storage. Nat. Chem. 2015, 7 (1), 19-29. https://doi.org/10.1038/nchem.2085.

(29) Terraschke, H.; Olchowka, J.; Geringer, E.; Rodrigues, A. V.; Wickleder, C. Facile Ionic LiquidAssisted Strategy for Direct Precipitation of $\mathrm{Eu}^{2+}$-Activated Nanophosphors under Ambient Conditions. Small 2018, 14 (17), 1703707. https://doi.org/10.1002/smll.201703707.

(30) Olchowka, J.; Hagemann, H.; Delgado, T.; Wickleder, C. The Influence of Ionothermal Synthesis Using $\mathrm{BmimBF}_{4}$ as a Solvent on Nanophosphor BaFBr:Eu ${ }^{2+}$ Photoluminescence. Nanoscale 2018, 10 (42), 19706-19710. https://doi.org/10.1039/C8NR06842A.

(31) Olchowka, J.; Suta, M.; Wickleder, C. Green Synthesis of $\mathrm{A}_{2} \mathrm{SiF}_{6}$ (A=Li-Cs) Nanoparticles Using Ionic 
Liquids as Solvents and as Fluorine Sources: A Simple Approach without HF. Chem. - A Eur. J. 2017, 23 (50), 12092-12095. https://doi.org/10.1002/chem.201702375.

(32) Recham, N.; Dupont, L.; Courty, M.; Djellab, K.; Larcher, D.; Armand, M.; Tarascon, J. M. Ionothermal Synthesis of Tailor-Made $\mathrm{LiFePO}_{4}$ Powders for Li-Ion Battery Applications. Chem. Mater. 2009, 21 (5), 1096-1107. https://doi.org/10.1021/cm803259x.

(33) Recham, N.; Chotard, J.-N.; Dupont, L.; Djellab, K.; Armand, M.; Tarascon, J.-M. Ionothermal Synthesis of Sodium-Based Fluorophosphate Cathode Materials. J. Electrochem. Soc. 2009, 156 (12), A993. https://doi.org/10.1149/1.3236480.

(34) Recham, N.; Chotard, J.-N.; Dupont, L.; Delacourt, C.; Walker, W.; Armand, M.; Tarascon, J.-M. A 3.6 V Lithium-Based Fluorosulphate Insertion Positive Electrode for Lithium-Ion Batteries. Nat. Mater. 2010, 9 (1), 68-74. https://doi.org/10.1038/nmat2590.

(35) Barpanda, P.; Ati, M.; Melot, B. C.; Rousse, G.; Chotard, J. N.; Doublet, M. L.; Sougrati, M. T.; Corr, S A.; Jumas, J. C.; Tarascon, J. M. A 3.90 v Iron-Based Fluorosulphate Material for Lithium-Ion Batteries Crystallizing in the Triplite Structure. Nat. Mater. 2011, 10 (10), 772-779. https://doi.org/10.1038/nmat3093.

(36) Choi, B. G.; Yang, M.; Jung, S. C.; Lee, K. G.; Kim, J.-G.; Park, H.; Park, T. J.; Lee, S. B.; Han, Y.-K.; Huh, Y. S. Enhanced Pseudocapacitance of Ionic Liquid/Cobalt Hydroxide Nanohybrids. ACS Nano 2013, 7 (3), 2453-2460. https://doi.org/10.1021/nn305750s.

(37) Olchowka, J.; Tailliez, T.; Bourgeois, L.; Dourges, M. A.; Guerlou-Demourgues, L. Ionic Liquids to Monitor the Nano-Structuration and the Surface Functionalization of Material Electrodes: A Proof of Concept Applied to Cobalt Oxyhydroxide. Nanoscale Adv. 2019, 1 (6), 2240-2249. https://doi.org/10.1039/C9NA00171A.

(38) Barpanda, P.; Chotard, J.-N.; Delacourt, C.; Reynaud, M.; Filinchuk, Y.; Armand, M.; Deschamps, M.; Tarascon, J.-M. LiZnSO ${ }_{4} \mathrm{~F}$ Made in an Ionic Liquid: A Ceramic Electrolyte Composite for Solid-State Lithium Batteries. Angew. Chemie Int. Ed. 2011, 50 (11), 2526-2531. https://doi.org/10.1002/anie.201006331.

(39) Olchowka, J.; Invernizzi, R.; Lemoine, A.; Allouche, J.; Baraille, I.; Flahaut, D.; Guerlou-Demourgues, L. Stabilization and Improvement of Energy Storage Performance of High Mass Loading Cobalt Hydroxide Electrode by Surface Functionalization. J. Electrochem. Soc. 2020, 167 (10), 100527. https://doi.org/10.1149/1945-7111/ab9a03.

(40) Lee, J.; Srimuk, P.; Zwingelstein, R.; Zornitta, R. L.; Choi, J.; Kim, C.; Presser, V. Sodium Ion Removal by Hydrated Vanadyl Phosphate for Electrochemical Water Desalination. J. Mater. Chem. A 2019, 7 (8), 4175-4184. https://doi.org/10.1039/C8TA10087J.

(41) Chauvel, B.; Bondot, P.; de Roy, M.; Besse, J. P. Spectroscopic Study of $\mathrm{VOPO}_{4}, 2 \mathrm{H}_{2} \mathrm{O}$ Intercalation Compounds. Mater. Res. Bull. 1991, 26 (6), 487-497. https://doi.org/10.1016/0025-5408(91)90189-S.

(42) Nguyen, L. H. B.; Sanz Camacho, P.; Broux, T.; Olchowka, J.; Masquelier, C.; Croguennec, L.; Carlier, D. Density Functional Theory-Assisted ${ }^{31} \mathrm{P}$ and ${ }^{23} \mathrm{Na}$ Magic-Angle Spinning Nuclear Magnetic Resonance Study of the $\mathrm{Na}_{3} \mathrm{~V}_{2}\left(\mathrm{PO}_{4}\right)_{2} \mathrm{~F}_{3}-\mathrm{Na}_{3} \mathrm{~V}_{2}\left(\mathrm{PO}_{4}\right)_{2} \mathrm{FO}_{2}$ Solid Solution: Unraveling Its Local and Electronic Structures. Chem. Mater. 2019, 31 (23), 9759-9768. https://doi.org/10.1021/acs.chemmater.9b03546.

(43) Kumar, P. R.; Jung, Y. H.; Lim, C. H.; Kim, D. K. $\mathrm{Na}_{3} \mathrm{~V}_{2} \mathrm{O}_{2 x}\left(\mathrm{PO}_{4}\right)_{2} \mathrm{~F}_{3-2 x}$ : A Stable and High-Voltage Cathode Material for Aqueous Sodium-Ion Batteries with High Energy Density. J. Mater. Chem. A 2015, 3 (12), 6271-6275. https://doi.org/10.1039/C5TA00980D.

(44) Li, C.; Shen, M.; Lou, X.; Hu, B. Unraveling the Redox Couples of $\mathrm{V}^{\mathrm{III}} / \mathrm{V}^{\mathrm{IV}}$ Mixed-Valent $\mathrm{Na}_{3} \mathrm{~V}_{2}(\mathrm{PO} 4)_{2}$ $\mathrm{O}_{1.6} \mathrm{~F}_{1.4}$ Cathode by Parallel-Mode EPR and In Situ/Ex Situ NMR. J. Phys. Chem. C 2018, 122 (48), 27224-27232. https://doi.org/10.1021/acs.jpcc.8b09151.

(45) Sauvage, F.; Quarez, E.; Tarascon, J.-M.; Baudrin, E. Crystal Structure and Electrochemical Properties vs. $\mathrm{Na}^{+}$of the Sodium Fluorophosphate $\mathrm{Na}_{1.5} \mathrm{VOPO}_{4} \mathrm{~F}_{0.5}$. Solid State Sci. 2006, 8 (10), 1215-1221. https://doi.org/10.1016/j.solidstatesciences.2006.05.009. Yokozeki, A.; Kasprzak, D. J.; Shiflett, M. B. Thermal Effect on C-H Stretching Vibrations of the 
Imidazolium Ring in Ionic Liquids. Phys. Chem. Chem. Phys. 2007, 9 (36), 5018. https://doi.org/10.1039/b706497g.

(47) Na, R.; Su, C.-W.; Su, Y.-H.; Chen, Y.-C.; Chen, Y.-M.; Wang, G.; Teng, H. Solvent-Free Synthesis of an Ionic Liquid Integrated Ether-Abundant Polymer as a Solid Electrolyte for Flexible Electric DoubleLayer Capacitors. J. Mater. Chem. A 2017, 5 (37), 19703-19713. https://doi.org/10.1039/C7TA05358D.

(48) Čapková, P.; Vácha, J.; Votinský, J. Anomalous Thermal Behaviour and Hydrogen Bond in $\mathrm{VOPO}_{4} \cdot 2 \mathrm{H}_{2} \mathrm{O}$. J. Phys. Chem. Solids 1992, 53 (2), 215-218. https://doi.org/10.1016/00223697(92)90047-H.

(49) Prechtl, M. H. G.; Campbell, P. S.; Scholten, J. D.; Fraser, G. B.; Machado, G.; Santini, C. C.; Dupont, J.; Chauvin, Y. Imidazolium Ionic Liquids as Promoters and Stabilising Agents for the Preparation of Metal(0) Nanoparticles by Reduction and Decomposition of Organometallic Complexes. Nanoscale 2010, 2 (12), 2601. https://doi.org/10.1039/c0nr00574f.

(50) He, G.; Kan, W. H.; Manthiram, A. A 3.4 V Layered $\mathrm{VOPO}_{4}$ Cathode for Na-Ion Batteries. Chem. Mater. 2016, 28 (2), 682-688. https://doi.org/10.1021/acs.chemmater.5b04605.

(51) Fang, Y.; Liu, Q.; Xiao, L.; Rong, Y.; Liu, Y.; Chen, Z.; Ai, X.; Cao, Y.; Yang, H.; Xie, J.; et al. A Fully Sodiated $\mathrm{NaVOPO}_{4}$ with Layered Structure for High-Voltage and Long-Lifespan Sodium-Ion Batteries. Chem 2018, 4 (5), 1167-1180. https://doi.org/10.1016/j.chempr.2018.03.006.

(52) Nguyen, L. H. B.; Olchowka, J.; Belin, S.; Sanz Camacho, P.; Duttine, M.; Iadecola, A.; Fauth, F.; Carlier, D.; Masquelier, C.; Croguennec, L. Monitoring the Crystal Structure and the Electrochemical Properties of $\mathrm{Na}_{3}(\mathrm{VO})_{2}\left(\mathrm{PO}_{4}\right)_{2} \mathrm{~F}$ through $\mathrm{Fe}^{3+}$ Substitution. ACS Appl. Mater. Interfaces 2019, 11 (42), 38808-38818. https://doi.org/10.1021/acsami.9b14249.

(53) Burova, D.; Shakhova, I.; Morozova, P.; Iarchuk, A.; Drozhzhin, O. A.; Rozova, M. G.; Praneetha, S.; Murugan, V.; Tarascon, J.-M.; Abakumov, A. M. The Rapid Microwave-Assisted Hydrothermal Synthesis of NASICON-Structured $\mathrm{Na}_{3} \mathrm{~V}_{2} \mathrm{O}_{2 \mathrm{x}}\left(\mathrm{PO}_{4}\right)_{2} \mathrm{~F}_{3-2 \mathrm{x}}(0<\mathrm{x} \leq 1)$ Cathode Materials for Na-Ion Batteries. RSC Adv. 2019, 9 (34), 19429-19440. https://doi.org/10.1039/C9RA02257K.

(54) Shakhova, I.; Rozova, M. G.; Burova, D.; Filimonov, D. S.; Drozhzhin, O. A.; Abakumov, A. M. Microwave-Assisted Hydrothermal Synthesis, Structure and Electrochemical Properties of the $\mathrm{Na}_{3} \mathrm{~V}_{2}$ ${ }_{\mathrm{Y}} \mathrm{Fe}_{\mathrm{y}} \mathrm{O}_{2 \mathrm{x}}\left(\mathrm{PO}_{4}\right)_{2} \mathrm{~F}_{3-2 \mathrm{x}}$ Electrode Materials for Na-Ion Batteries. J. Solid State Chem. 2020, 281, 121010. https://doi.org/10.1016/j.jssc.2019.121010.

(55) Palomares, V.; Iturrondobeitia, A.; Sanchez-Fontecoba, P.; Goonetilleke, D.; Sharma, N.; Lezama, L.; Rojo, T. Iron-Doped Sodium-Vanadium Fluorophosphates: $\mathrm{Na}_{3} \mathrm{~V}_{2-\mathrm{y}} \mathrm{O}_{2-\mathrm{y}} \mathrm{Fe}_{\mathrm{y}}\left(\mathrm{PO}_{4}\right)_{2} \mathrm{~F}_{1+\mathrm{y}}(\mathrm{y}<0.3)$. Inorg. Chem. 2020, 59 (1), 854-862. https://doi.org/10.1021/acs.inorgchem.9b03111.

(56) Zhang, Z.; Chen, Z.; Mai, Z.; Peng, K.; Deng, Q.; Bayaguud, A.; Zhao, P.; Fu, Y.; Yu, Y.; Zhu, C. Toward High Power-High Energy Sodium Cathodes: A Case Study of Bicontinuous Ordered Network of 3D Porous $\mathrm{Na}_{3}(\mathrm{VO})_{2}\left(\mathrm{PO}_{4}\right)_{2} \mathrm{~F} / \mathrm{RGO}$ with Pseudocapacitance Effect. Small 2019, 15 (14), 1-8. https://doi.org/10.1002/smll.201900356.

(57) Xu, M.; Wang, L.; Zhao, X.; Song, J.; Xie, H.; Lu, Y.; Goodenough, J. B. $\mathrm{Na}_{3} \mathrm{~V}_{2} \mathrm{O}_{2}\left(\mathrm{PO}_{4}\right)_{2} \mathrm{~F} / \mathrm{Graphene}$ Sandwich Structure for High-Performance Cathode of a Sodium-Ion Battery. Phys. Chem. Chem. Phys. 2013, 15 (31), 13032. https://doi.org/10.1039/c3cp52408f.

(58) Liu, S.; Wang, L.; Liu, J.; Zhou, M.; Nian, Q.; Feng, Y.; Tao, Z.; Shao, L. $\mathrm{Na}_{3} \mathrm{~V}_{2}\left(\mathrm{PO}_{4}\right)_{2} \mathrm{~F}_{3}-\mathrm{SWCNT}$ : A High Voltage Cathode for Non-Aqueous and Aqueous Sodium-Ion Batteries. J. Mater. Chem. A 2019, 7 (1), 248-256. https://doi.org/10.1039/C8TA09194C.

(59) Väli, R.; Möller, P.; Jänes, A. Synthesis and Characterization of $\mathrm{Na}_{3} \mathrm{~V}_{2}\left(\mathrm{PO}_{4}\right)_{2} \mathrm{~F}_{3}$ Based Cathode Material for Sodium Ion Batteries. ECS Trans. 2015, 69 (39), 27-36. https://doi.org/10.1149/06939.0027ecst. 


\section{For Table of Contents Only}

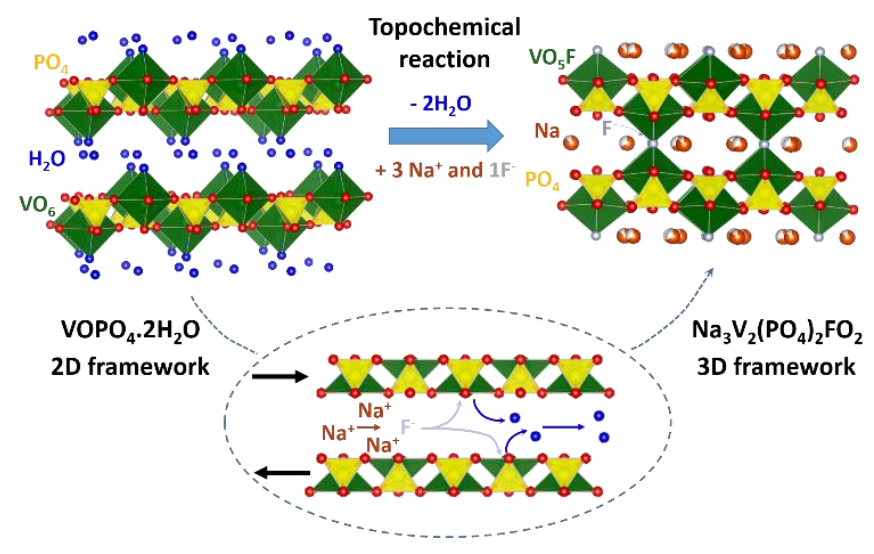

In this work, ionothermal synthesis leading to controlled-morphology of $\mathrm{Na}_{3} \mathrm{~V}_{2}\left(\mathrm{PO}_{4}\right)_{2} \mathrm{FO}_{2}$ electrode material is developed. A topochemical mechanism is proposed to explain the formation of platelet-like $\mathrm{Na}_{3} \mathrm{~V}_{2}\left(\mathrm{PO}_{4}\right)_{2} \mathrm{FO}_{2}$ starting from layered $\alpha-\mathrm{VOPO}_{4} \cdot 2 \mathrm{H}_{2} \mathrm{O}$ and the effect of this peculiar morphology on the electrochemical performances of the as-prepared material are investigated and disccused. 